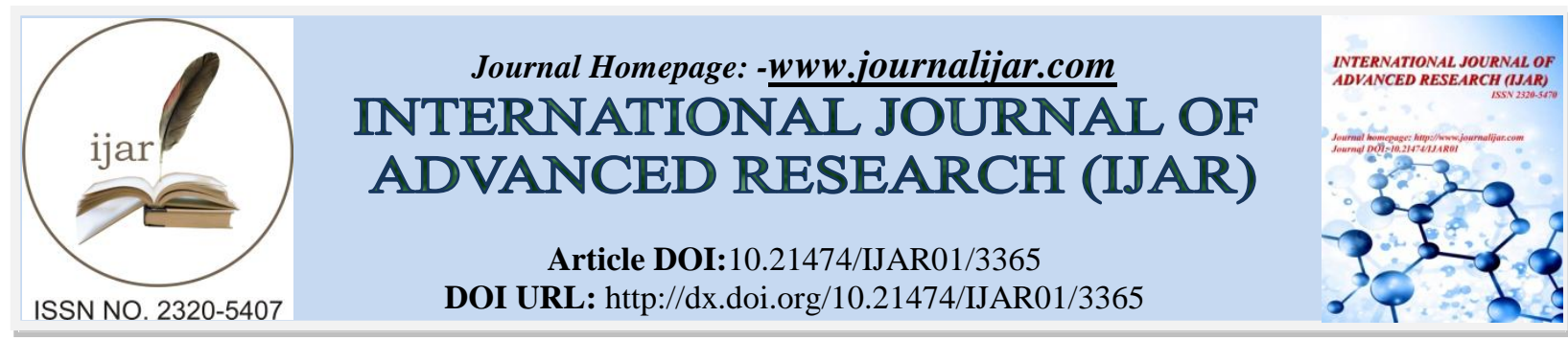

RESEARCH ARTICLE

\title{
CIVIL RIGHTS OF CUSTOMARY LAW PEOPLE IN THE COASTAL AREA,A REVIEW OF CONSTITUTIONAL RIGHTS
}

\author{
Merry Tjoanda. \\ Faculty of Law, University ofPattimura, Jl. Ir. M. Putuhena - KampusPoka, Ambon, Maluku 97233, Indonesia.
}

\section{Manuscript Info}

Manuscript History

Received: 24 December 2016

Final Accepted: 15 January 2017

Published: February 2017

Key words:-

Constitutional Rights, Customary Law

People, Civil Rights, Coastal Area

\section{Abstract}

A claim of State to the sea territorial ownership as a right to control the State, its purpose for the greatest prosperity of the people, but can interact directly with civil rights to customary law people in the coastal areas. The potential for conflict is caused due to the conflict over the ownership of the natural resources management and its utilization in the coastal areas between customary law people and state. On one hand, the 1945 Constitution provides assurance, recognition and respect for the unity of customary law peoples and their traditional rights as constitutional rights. But on the other hand, the state must intervene in the natural resources management in the coastal areas, because sea has a public function, and allow anyone to exploit the sea for various purposes. This means that the need for legal recognition explicitly against the civil rights of customary law people in the coastal areas in natural resources management and its utilization. Thus, the authority of state to defends the people's interests, in line with the interests of customary law people rights to defend their civil for the survival of their lives in the future.

Copy Right, IJAR, 2017,. All rights reserved.

\section{Introduction:-}

Coastal and marine areas have a strategic meaning and important for the future of Indonesia as the largest archipelago state in the world. Indonesia as the largest archipelago state in the world, which has a long coastline of $81.000 \mathrm{~km}$ and about $22 \%$ of the total population of Indonesia inhabit coastal areas. ${ }^{1}$ This includes the majority of customary law people living in the coastal areas, and the coastal areas that provided life from generation to generation for concerned customary law people alliance.

Accordingly, Indonesia is an example of a "large coastal nation" in thesame category as Australia, the United States and Canada. ${ }^{2}$ Wehave large-scale geographic issues such as a broad range ofclimates, ecosystems, community structures and diversesociocultural groups. Distance and remoteness are significantfactors for communication and

\footnotetext{
${ }^{1}$ Processed of Statistical Date Center and Information (KKP),the Ministry of Marine and Fisheries, Indonesia 2013. Available online at: http://statistik.kkp.go.id/

${ }^{2}$ RokhminDahuri, "The Challenges of Public Policy for SustainableOceans and Coastal Development: New Directions inIndonesia", in Ministerial Perspective on Ocean and Coasts atRio+10, The Global Conference on Oceans and Coasts.December 3-7, Unesco, Paris, 2001,
} 
governance. Indonesia can alsobe seen, paradoxically, as a "small island nation' in the samecategory as the Philippines and Micronesia with small-scaleissues.

The existence of customary law people has been recognized by the state that "the State recognizes and respects the unitary of customary law people and their traditional rights as long as they live and in accordance with the development of society and the principles of the Unitary Republic of Indonesia". ${ }^{3}$ This statement is the foundation for customary law people to claim their constitutional rights, so how should the state act to treat customary law people to gain recognition and respect for their traditional rights. In other words, the meaning contained in Article 18B paragraph 2 of the 1945 Constitution is a constitutional mandate that needs to be adhered by the government, to regulate the recognition and respect for customary peoples in legislation.

Besides customary law people have the right, in fact also have obligations to land and natural resources around them. Between the rights and obligations there must be a strong balance so as to form the management of the environment and natural resources that integrates the social, political, natural, cultural, and religious from the life of customary law people. ${ }^{4}$ Soegiarto argues that, "beside the coastal areas as the center of activity is also can become the center of conflict or clash between the interests of one sector to others.",

The tenure area (land and marine) including the natural resources therein should be managed in a sustainable manner. To be managed in a sustainable manner, then right to the tenure area need to be on the indigenous peoples based on customary law prevailing in the area. This is important because in their mind the indigenous peoples are bound in communal and religious-magical (cosmic). Such mind views everything in this life as a homogeneous unity, in which human life affect each other and are interdependent on each other. All are in a balance should always be maintained. ${ }^{6}$

The phenomenon that occurs associated with the ownership and natural resources management in the coastal areas still leaves internal conflicts between the state authorities and indigenous peoples. On the one hand, the state claimed that the management of coastal areas as domain of state, while on the other hand, the rights of customary law people to the tenurerights of coastal areas is a part that cannot be removed apart from the customary law life, and it is constitutionally recognized by the state. ${ }^{7}$ The reality of civil rights in coastal areas has actually become the property of the customary law people, but its allocation is often claimed to be the property of the state. As described above, the issue of this researchwas to analyze the civil rights of the customary law people in the coastal areas in Indonesia.

\section{Method of the Research:-}

The type of study was a normative research, with the object of study on the provisions of applicable law, both nationally and internationally, in order to answer the issues faced. The approaches used in this research were statute and conceptual.

\section{Civil Rights in Normative Perspective: -}

Legal protection against the customary law people is closely associated with the right. According to George W. Paton, ${ }^{8}$ that there are 4 (four) elements in any legal rights, which are: "(1) the holder of the right; (2) the act or forbearance to which the right relates; (3) the rest concerned (the object of the right); (4) the person bound by the duty."

\footnotetext{
${ }^{3}$ Article 18B paragraph (2) of the 1945 Constitution of the Unitary State of the Republic of Indonesia.

${ }^{4}$ Ronald Titahelu, Paper on Indonesian Legal Center for Community Based Property Rights and Marine and Coastal Resources Management.

${ }^{5}$ AprilianiSoegiarto. (1988). PemanfaatanSumberAlamLautMenjelangTahun 2000 di dalamStrategiKelautan, in John Pieris (ed). PustakaSinarHarapan, Jakarta, p. 42.

${ }^{6}$ Soepomo. (1996).Bab-Bab Tentang Hukum Adat.Jakarta: Balai Pustaka, p. 77

${ }^{7}$ Charles, A.T. (2001). Sustainable Fishery Systems. London, UK: Blackwell Sciences, p. 92

${ }^{8}$ George Whitecross Paton, A Texbook of Jurusprudence, 3rd ed., Univercity Press, Oxford, 1964, p. 249
} 
Rights are all things that must be obtained by any person who has been there since birth and even before birth. In the Indonesia's Dictionary a right has a sense of the right thing, property, ownerships, authority, power to do something (as determined by the Acts, rules, etc.), power is right on something or to demand something, degree or dignity. ${ }^{9}$

When talking about civil rights, then it is very closely related to the rule of law governing those rights. An understanding of civil rights is actually composed of two types of civil rights: First, the right is absolute, includes: a) The right of personality, for example: the rights to name, to honor, to life, liberty and so forth; b) The rights located in family law, that is rights and duties of husband and wife, the relation of parent and child; c) absolute right to the object, is called as the right of material. Second, the right is relative, that is, all rights arising from the engagement relationships that sourced in the agreement and law. This right is called as the rights of individuals. ${ }^{10}$

Absolute right of land ownership as an immobile object can be owned by humans, and are included in the category of material rights. "Article 499 of Civil Code/BW can also know the sense of objects as all things that can be owned or which may become the object of property rights". "The provision gives a description that everything that can be owned by human is object, so that cannot be had for example the sea, moon, stars and so on, not anobject.",12

Land tenure rights as in Act No. 5 of 1960 on the Basic Regulation of Agrarian (BAL) contains several levels of land tenure, namely: 1) Right of Indonesia nation; 2) Right to control of the State; 3) Tenure rights of customary law people; 4) Individual rights. Explained that the right to control the state set out in Article 2 of the BAL, the authority contained in the right to control of the state is a public authority, so that this right is not similar as the concept of the domains imposed by the Dutch colonial government. ${ }^{13}$

Customary rights as a part of civil rights owned by the customary law people, as stipulated in Article 3 of the BAL, according to BoediHarsonothat customary rights is "a series of authorities and duties of a customary law people relating to the land located within the territory. The subject of the customary rights are customary law people, both territorial (living in the same area) and genealogic (bound by ties of blood). Thus, the customary rights land that has been occupied by the customary law people since long time ago it is part of state-owned land. Thus, the argument of BoediHarsono provide an understanding that the customary rights of indigenous peoples are not categorized as belonging to the customary law people.

Civil caw especially Indonesian agrarian law illustrates that in fact "there is no inch of land at the Indonesian state is what is called res nullius or no mans' land." "While in a customary law perspective looked for the principle of res nulliusas communal land ownership and it is not transferable to the individual. Humans as right users in its relation to the rights of state, then Civil Code, Article 1, explains, "Enjoyed civil rights cannot depend on state rights". 15

The customary rights of sea or marine tenure in Maluku are related to the concept of ownership. An understanding of the marine tenure when linked to the marine tenure in Maluku province, the concept of ownership is reflected in the "marine tenure region" which in the aspect of boundaries shows the boundaries of tenure region is unclear. In other words, the rightsof marine tenure as a concept of ownership by the customary law people are clearly exist and be recognized. However, differences in the perception of boundaries of marine tenure area are based on a different understanding between the peoples of each region (customary villages) is a matter that cannot be denied. ${ }^{16}$

\footnotetext{
${ }^{9}$ Source: https://id.wikipedia.org-wiki-hak, downloaded on 14 April 2016.

${ }^{10}$ Djaja S. Meliala.(2007).Perkembangan Hukum Perdata Tentang Orang Dan Hukum Keluarga, Bandung: CV. Nuansa Aulia, p. 38.

${ }^{11}$ F.X. Suhardanaet al. (2001).Hukum Pedata I: Bukum Panduan Mahasiswa.Jakarta: Prenhallindo, p. 148

${ }^{12}$ Ibid.

${ }^{13}$ Boedi Harsono. (2005).Hukum Agraria Indonesia: Sejarah Pembentukan Undang Undang Pokok Agraria, Isi dan Pelaksanaannya.Jakarta: Djambatan, p. 268.

${ }^{14}$ BoediHarsono. (1997). HukumAgraria Indonesia (Sejarah PembentukanUndang-UndangPokokAgraria, Isi danPelaksanaannya), 7th edition. Jakarta:Djambatan, p. 217.

${ }^{15}$ Djaja S. Meliala. Op.Cit. p. 37

${ }^{16}$ S.E.M. Nrahua, 29 March 2016, A Paper presented on FGD Recognition, Protection and Legal Certainty for Customary Law, In Cooperation with Postgraduate Program University of Pattimurawith Social Science Commission of Akademi Pengetahuan Indonesia (AIPI), Ambon, Page. 2
} 
Although according to the law, every human being is a bearer of rights without exception, but there are restrictions. Elements that limit for the right is: a) Citizenship; ${ }^{17}$ b) Residential; ${ }^{18}$ c) Position; ${ }^{19}$ d) Behavior and deed; ${ }^{20}$ e) Gender; $\mathrm{f}$ ) the condition of absenteeism (Article 463 of the Civil Code). ${ }^{21}$

\section{Customary Law People as Constitutional Guarantees: -}

The term of "indigenous peoples" is a common term used in Indonesia, whereas in the science of law and theory are formally known as "customary law people." ${ }^{22}$ The sense of indigenous people and customary law people in this paper is same its meaning. The State recognizes and respects the unity of indigenous peoples and their traditional rights as long as they live, and in accordance with the development of society and the principles of the Unitary State of the Republic of Indonesia, which is regulated by law. ${ }^{23}$ So, through the constitution, the State recognizes and respectsthe unity of indigenous peoples and the rights attached to it as the living law.

Recognition of the unity of indigenous peoples should be respected and upheld by the state, due to the fact that the lives of indigenous peoples in Indonesia have existed long before the state there. ${ }^{24}$ The state should provide protection of the rights inherent in customary law peoples, such as marine tenure rights in the coastal areas. Hence, in the 1945 Constitution, states that "The cultural identity and traditional community right must be respected in accordance with the period and civilizations." 25 Therefore, according to Asshiddiqie on the categories of indigenous people can be said to be still living in reality, as follows:

1. The communities are still indigenous, the tradition is still practiced, and available records on that tradition;

2. The communities are still indigenous and also their traditions exist, but the records are not available;

3. The communities are not indigenous anymore, but their tradition is still practiced and also provided adequate records;

4. The communities are not indigenous anymore, and also not available records about it, but their tradition is still alive in practice. ${ }^{26}$

Definition of customary law people according to Act No. 1 of 2014 on the amendment of Act No. 27 of 2007 on the Management of Coastal Areas and Small Islands were "the coastal communities group for generations living in a particular geographical area because of their ties the ancestral origin, the existence of a strong relationship with the coastal resources and small islands, as well as their value system which determines the economic system, political, social, and legal." 27 While,the meaning of coastal area as transition regions between terrestrial and marine ecosystems are affected by land and marine changes.

The scope of regulation of coastal areas and small islands includes the transition between the terrestrial and marine ecosystems are affected by changes in land and marine, towards the land covering the sub-district administration area and towards the marine covering as far 12 (twelve) miles measured from the coastline. Samik Wahab argued

\footnotetext{
${ }^{17}$ Only Indonesian Citizen who has the property right (See: Article 21 (1) UUPA).

${ }^{18}$ Only who living in the same sub-district with the position of agricultural land as the owner (See: Article 10 (2) UUPA).

${ }^{19}$ For a judge and other law officials are not obtaining the goods that still in a case.

${ }^{20}$ See, Article 49 and 53 of Act No. 1 of 1974, in which regulate the provisions that the power of parent and guardian may be evoked with the court's decision and in this case is very neglected duties as parent/guardian behave badly.

${ }^{21}$ F.X. Suhardana et al. (2001).Hukum Pedata I: Bukum Panduan Mahasiswa, Prenhallindo, Jakarta, Pages. $46-47$.

${ }^{22}$ Source: https://id.wikipedia.org/wiki/Masyarakat_adat., accessed on 16 April 2016.

${ }^{23}$ Article 18B paragraph (2) of the1945 Constitution.

${ }^{24}$ Ibrahim, J., \&Haykal, H. (2016). Religious Communal of Indigenous Peoples in Improving Economy Through Local Wisdom (A Juridical Study on Rural Credit Institution in Bali). Hasanuddin Law Review, 1(1), 89-98. doi: http://dx.doi.org/10.20956/halrev.v1i1.216

${ }^{25}$ Article 28I paragraph (3)of the 1945 Constitution.

${ }^{26}$ JimlyAsshiddiqie.(2007).HakKonstitusionalMasyarakatHukumAdat, A Paper Presented on National Workshop, Jakarta 10 December 2007. p. 10.

${ }^{27}$ See Article 1 paragraph (33) Act No. 1 of 2014 on the Amendment of Act No. 27 of 2007 on the Management of Coastal Area and Small Islands.
} 
that, "the coastal area that will cover all areas inland were still influenced by processes related to the marine and toward the marine are still influenced by processes that occur on the inland. ${ }^{28}$

In general, civil rights for the customary law people may be right is absolute, in which the right to respect for recognized the existence of the customary law people, the right to live and to have a decent living in their area, and also the absolute right of an object/material already has for generations, such as customary rights consist of land, water and natural resources.Furthermore, Bushar Mohammed, ${ }^{29}$ said the object of customary rights includes: land; water (such as: river, lakes, beaches and its waters); the plants that live in the wild (fruit trees, trees for timber or firewood, and so on); and free-living wild animals in the forest.

Depart from the construction, this means that among the civil rights of customary law people that inhabit coastal areas may be customary rights on the mainland and in coastal marine waters. If it can be described civil rights to those that can be managed by customary law people, civil rights in the sea waters may be; fish, sea cucumber, shellfish, seaweed, reef, beach sand, gravel, and mangroves. While, the civil rights of customary law people in the mainland may be; land/forest, fruit trees, trees for timber or firewood, and wild animals. Utilization of civil rights in the form of natural resources, conducted to maintain the viability of customary law people that inhabit coastal areas.

In fact, at historical level, the rights of customary law people in coastal areas are already there all along, but needs to be reinforced by the rule of law, so that there is legal certainty which protects the interests of customary law people in the coastal areas. And neededthe customary law people be given the rights and duties under the law, which must be met related to the use and management of coastal areas, in which the rights of customary law people were:

(a) Get access to coastal waters parts that have been given a permit of location and use it;

(b) Propose a traditional fishing area in the Zoning Plan for Coastal Areas and Small Islands (RZWP-3-K);

(c) Propose the territories of customary law people in RZWP-3-K;

(d) Perform the management of coastal resources and small islands is based on customary law and not contrary to the provisions of the legislation;

(e) Get the benefits of the implementation of the management of coastal areas and small islands;

(f) Get information regarding the management of coastal areas and small islands;

(g) Propose reports and complaints to the competent authorities for losses to them with regard to the implementation of the management of coastal areas and small islands;

(h) Declare an objection to a management plan that has been declared within a certain period;

(i) Report to law enforcement officers for alleged pollution, contamination, and/or destruction of coastal areas and small islands is detrimental to life;

(j) Propose a complaint to the court against various problems of coastal areas and small islands is detrimental to life;

(k) Obtain compensation; and

(1) Get assistance and legal aid to the problems faced in the management of coastal areas and small islands in accordance with the provisions of the legislation. ${ }^{30}$

The duties of customary law people in the management of coastal areas and small islands are to:

(a) Give information regarding the management of coastal areas and small islands;

(b) Maintain, protect, and preserve the coastal areas and small islands;

(c) Inform report the occurrence of hazards, pollution, and/or damage to the environment in coastal areas and small islands;

(d) Monitor the implementation of the plan of management of coastal areas and small islands; and/or

(e) Implementing the program of the management of coastal areas and small islands as agreed at the village level.

Also, the legislation provides duties for governments to take the customary law people in the management of coastal areas, that:

(1) Government and local government are obliged to empower communities to improve their welfare.

\footnotetext{
${ }^{28}$ A. Samik Wahab.(1998).Perobahan Pantai danKajian Pembangunan Pantai Utara Jawa Tengah.(Report). LPMGadjahMada University, p. 37

${ }^{29}$ Bushar Muhammad. (1983).Pokok-pokokHukumAdat.Jakarta:Pradnya Paramita, p. 109

${ }^{30}$ See Article 60 paragraph (1) Act No. 1 of 2014 on the Amendment of Act No. 27 of 2007 on the Management of Costal Area and Small Islands
} 
(2) Government and local government shall encourage business activity of communities through capacity building, provision of access to technology and information, capital, infrastructure, market guarantees, and other productive economic assets.

(3) In order for community empowerment, the government and local governments realize, develop, and increase awareness and responsibility in:

(a) Decision-making;

(b) Implementation of management;

(c) The partnership between the community, business, and government/local government;

(d) The development and implementation of national policies in the field of environmental;

(e) The development and implementation of preventive and proactive efforts to prevent a decrease in the carrying capacity and the capacity of coastal areas and small islands;

(f) The use and development of environmentally friendly technologies;

(g) Supplying and dissemination of environmental information; and

(h) Awarding to those who contributed in the field of management of coastal areas and small islands.

(4) Further provisions concerning the guidelines for community empowerment regulated by the regulation of the minister. $^{31}$

The reason the issuance of provisions regarding guidelines for community empowerment is regulated by the Regulation of the Minister of Marine Affairs and Fisheries of the Republic of Indonesia Number40/PermenKP/2014 concerning participation and communities' empowerment in the management of coastal areas and small islands, by give attention to the dynamics of participation and communities empowerment in the coastal areas. The purpose of this minister's regulationas basis and reference for the Ministry, local government, stakeholders and the public to realize participation and community empowerment in the management of coastal areas and small islands (PWP-3-K). With the aims toimprove the effectiveness and sustainability in utilization of coastal areas and small islands; to improve the capacity and independence of the community to participate in PWP-3-K; to assure and protect the public interests in utilize coastal resources and small islands in a sustainable manner; and to strengthening the values of local wisdom to support the nation-building process in PWP-3-K. ${ }^{32}$ That is, the customary law people have authority to use and manage natural resources in the coastal areas.

AbrarSaleng, ${ }^{33}$ provides insight into the relationship of similarities and differences between customary rights with the right to state's control, namely:

a) Subject, for customary rights is the legal community, not individuals, while for the right to state's control is the state.

b) Object, for customary rights are land, water and natural resources (limited) in their territory, while the right to state's control is more widely, because in addition to all natural resources that exist in the territory of Indonesia, also the branches of production which are important for the state and dominate the life of many people.

c) Content, for customary rights is a series of authorities and responsibilities includes: rule, giving way use of natural resources and maintenance, while the right to state's control are a number of authorities and public duties which include the setting, maintenance and monitoring of the use and utilization of all potential natural resources and the branches of production for the welfare of the people.

d) Implementer, for customary rights is the Head of Law Alliance or Customary Chief, whereas for the rights of state's control is Government of the Republic of Indonesia.

A result of research by Professor R.Z. Titahelu, ${ }^{34}$ against customary law people and the local communities that inhabit coastal areas and small islands in Maluku in managing natural resources on land and coastal and marine, have rules more or less is similar. Titahelu concluded that:

\footnotetext{
${ }^{31}$ See Article 63 paragraph (1) Act No. 1 of 2014 on the Amendment of Act No. 27 of 2007 on the Management of Costal Area and Small Islands

32 See Article 3 the Minister's Regulation of Marine and Fisheries Affairs of the Republic of Indonesia No. 40/Permen-KP/2014 on Participation and Communities Empowerment in the Management of Coastal Area and Small Islands

${ }^{33}$ AbrarSaleng. (2004). HukumPertambangan, Yogyakarta: UII Press, p. 52

${ }^{34}$ Ronald Z. Titahelu. (2014).Aneka Masalah Masyarakat Hukum Adat Dalam Pembangunan.Yogyakarta:Deepublish, p. 32-33
} 
1) The coastal and marine resources in coastal villages and small islands, in some places used for living or for commercial purposes, while in others only used to sustain life only.

2) Recognition of government for the local/traditional management is important for people to achieve prosperity and environmental sustainability. Government recognition of community rights over the natural resources management (traditional fishermen or coastal community rights and natural resource management) should be legalized.

3) The rights of communities and authorities for natural resources management is a right that is not based on the administration of the state.

4) Recognition has more meaning for declarative statement rather than constitutive. More importantly, the recognition of the government should give effect to the public confidence that people have the capacity themselves to improve their lives better by practicing the local/traditional management to the natural resources around them.

5) Recognition of government affects the sense of local/traditional peoples in which they have ability to improve the living standards of their own to manage the resources around them. Legal recognition by the government is necessary.

6) It has consequences for community's lives. Traditional or local management is a reflection of the communities' condition, although for some conditions may change, because the community has dynamic life as they develop of current circumstances.

Titahelu's research emphasizes two key ingredients, that is: First, the people's right to manage the coastal and marine resources around them because it is assumed that they have ability to improve the living standards of their own; Second, the government's recognition of the rights of community is a requirement for people to achieve prosperity and sustainability of the environment. ${ }^{35}$ This indicates a positive meaning that the development of people's political oversight in the utilization of natural resources, particularly in the coastal and marine resources does not come about through good will of the government solely.

In general, RohminDahuri ${ }^{36}$ describing about coastal and marine environment as a source of "common property resources", so it has the function of public/public interest; sea is an "open access", allowing anyone to take advantage of ocean space for various purposes; sea is "fluid", where resources (marine) and hydro-oceanography dynamics cannot be partitioned; the coastal is a strategic area because it has the topography is relatively easy to develop and have a very good access (by utilizing the sea as movement "infrastructure"); the coastal area is rich in natural resources, both in the mainland and waters, which is needed to meet human needs.

Based on the statement above, it can be explained that there are differing ideas about the concept of coastal area management, that on the one hand the management of coastal and marine areas to allow anyone to take advantage of ocean for various purposes. On the other hand, argued that the interests of open access that make the coastal area as a resource that is not clear its tenure, so it is said that access to this resources is not regulated and open to anyone. Then, because the sea or marine as a common property resources has a public function in the public interest, and allow anyone to take advantage of ocean for various purposes, making the state should intervene in the natural resources management in the coastal and marine areas, for the achievement of equality and justice for all people, especially for local people or local customary law people.

The authority of State to control natural resources in Indonesia, stipulated in the 1945 Constitution of the Republic of Indonesia, describes that "earth and water and natural resources contained in it are controlled by the State and used for the greatest prosperity people". ${ }^{37}$ Based on this statement, then the formulation of the meaning of State's control rights is to the natural resources management. According to P.M. Faiz, ${ }^{38}$ state through the government has authority to decide on the use, utilization and rights to natural resources to regulate, administer, manage, and supervise the management and utilization of natural resources. Therefore, the natural resources that are important to

\footnotetext{
${ }^{35}$ Ibid., 33-34

${ }^{36}$ RohminDahuri. (2003).ParadigmaBaru Pembangunan Indonesia BerbasisKelautan, (Scientific Oration),InstitutPertanian Bogor, Indonesia, p.15

${ }_{38}^{37}$ Article 33 paragraph (3)of the 1945 Constitution.

38 Pan Mohammad Faiz, PenafsiranKonsepPenguasaan Negara BerdasarkanPasal 33 UUD 1945 danPutusanMahkamahKonstitusi, $\quad$ http://jurnalhukum.blogspot.com/2006/10/penafsiran-konsep-penguasaannegara.html, accessed on 15 December 2014.
} 
the State and dominate the people, as it relates to the public utilities and public services, must be dominated by State and run by the government, where those resources should be enjoyed by the people in fairness, affordability, in an atmosphere of prosperity and general well-being are fair and equitable.

The principle of res publicae in publicousu, enabling the State to get authority to determine the use and utilization of resources in the public interest, it can be found in the form of State has the right to control the land, that "the State can perform a legal relationship such as individual objects with human as owner. Legal relation with the land included in the category of objects or land that used for public (res publicae). Thus, public roads and likes belong to the State". 39

\section{The Problem of Right Proprietary to Manage Coastal Area:-}

Neil Meyer, ${ }^{40}$ a professor who is an expert in the field of agriculture, economics and rural sociology at the University of Idaho argues that "the problem of coastal areas and the development and management of which was never completed due to the system of open access that developed without any reinforcement by the State for the benefit of the coastal community. State's intervention that makes all coastal area, marine, including small island as objects of state ownership so that its arrangements managed by the State."

In conceptual can be said, the dualism of rights proprietary to manage the coastal area, which is between the State and the customary law people. Related to that, AbrarSalengargues their relationship is actually the similarities and differences between customary rights with the rights of State's control are: ${ }^{41}$

a) Subject, for customary rights is the legal community, not individuals, while for the right to state's control is the state.

b) Object, for customary rights are land, water and natural resources (limited) in their territory, while the right to state's control is more widely, because in addition to all natural resources that exist in the territory of Indonesia, also the branches of production which are important for the state and dominate the life of many people.

c) Content, for customary rights is a series of authorities and responsibilities includes: rule, giving way use of natural resources and maintenance, while the right to state's control are a number of authorities and public duties which include the setting, maintenance and monitoring of the use and utilization of all potential natural resources and the branches of production for the welfare of the people.

d) Implementer, for customary rights is the Head of Law Alliance or Customary Chief, whereas for the rights of state's control is Government of the Republic of Indonesia.

Thus, the central- and localgovernment and the legislature as well as the unity of indigenous peoples in this case the agency has authority to recognize, justify and accept the rights of customary law people, need to understand several aspects, as follows: ${ }^{42}$

First; the authority for the territories of customary law people. Customary law people know very well their territory with clear boundaries obtained through a long historical process. Therefore, indigenous people need to communicate their communal land to surrounding communities, governments, and other parties by using similar language (media). This implementation can be to use a map, where in making a map is conducted in participative and in a simple technique, so that themap will be an effective tool to discuss the overlap of a region in their authority. The clarity of authority over the territory of customary law people can be done by agreement and acknowledgment by the surrounding community. Furthermore, requires explicit recognition from the government to the territory of customary law people was not transferred to another party, while ensuring the forest resources can be utilized. Clarity form of the customary law people's authority can be done in the form of legal recognition of the customary law people by State Land Agency. In the case of the territory of customary law people first be given before the

${ }^{39}$ E. Algra. (1985).Inleiding tot het NedherlandsPrivaatrecht, W.E.J. TjeenkWillink, Zwolle, achtiendedruk, p. 121; WinahyuErwiningsih.(2009)."PelaksanaanPengaturanHakMenguasai Negara atas Tanah Menurut UUD 1945”, JurnalHukum, Special Issue: 118-136

${ }^{40}$ As cited on WALHI, Briefing Haper $\quad$ Hing, DampakPolitikRejimKorporasiTerhadapSumberDayaPesisirdanPulau-Pulau Kecil di Indonesia DiTengah SituasiPerubahanIklimdanKrisisPangan Nasional.

${ }^{41}$ AbrarSaleng, Op.Cit., p. 52

${ }^{42}$ BesseSugiswati.(2012)."PerlindunganHukumTerhadapEksistensiMasyarakatAdat JurnalPerspektif,17(1): 31-43.

$\mathrm{Di}$ Indonesia" 
decree is published, it can be negotiated by the parties concerned (customary law people in the territory, right giver and right recipient).

Second, it is the authority of customary institutions. The authority of a territory of customary law people is needed to prevent dual-recognition or recognition for a territory that is not its authority. In this case, there are several possibilities that can be done: 1. Recognition of the existence of indigenous peoples by the indigenous people themselves and from surrounding community about their institutional authority; 2. Recognition of the existence of indigenous peoples by the judiciary based on court decisions; 3 . Recognition of the existence of indigenous peoples by a Council of Indigenous Peoples are elected by the indigenous peoples themselves.

Third, the authority on the pattern forest resource management. Management pattern that carried out by customary law people in general is based on the existing indigenous knowledge and grow in the community with all norms that regulate limitations and sanctions. This pattern is developing very dynamically in accordance with the times. Generally, these dynamic nature does not explicitly define the form of natural resource management; such as forest, farm or agricultural, so it requires sufficient understanding by local governments on these patterns.

The basic character of the rights proprietary of indigenous people over natural resources has the meaning of joint ownership or communal, so the characteristic of right collectivity of indigenous people over customary rights sourced from the concept of natural law with judicialnature, it means the judicial nature the natural law would lose its meaning, thus there are some juridical nature inherent in the natural law, as follows: ${ }^{43}$

a) Applicability of the natural laws does not depend on enforced or not the rules of natural law by the authorities.

b) Natural law is the direction of the attitudes and human nature.

c) The rules of natural law would apply even if no orders from the authorities to enforce the natural law.

d) Applicability of the natural law in spite of the enactment of positive law.

e) Natural law is the supreme law of human, so that the enactment of legislation in the positive law cannot exclude the existence of the rules of natural law.

f) Natural law applies anywhere and anytime.

g) The rules of natural law are discovered by human's mind and rational.

h) The basics of natural law derived from the legal norms and morals.

i) There is an opinion stating that the rules of natural law are nothing other than the shadow of a concept of utilitarianism thought and moral principles.

j) There is also the theory of traditional character, namely natural law theory of positive law.

Based on the understanding above, it should the meaning of civil rights to the customary law people in coastal areas becomes clear that is these rights should not be ruled out with the rules of existing positive law.

\section{Conclusion:-}

The proprietary of civil rights of indigenous people in coastal areas to be so important, because the right proprietary to manage and utilize the natural resources in coastal areas already exist and belong to the customary law people before this State exist. Thus, the utilization of coastal and marine areas that are open access need to be reviewed, arguing there should be a boundary, because basically coastal areas it is the property of a unity of customary law people that inhabit coastal areas. This means that the management and utilization in coastal areas that are intended for anyone to be able to manage it, must be known and received permission from the local customary law peoples. Hence, neededa rule of law are clear and explicit to prevent the conflict of authority between the State and the proprietary of civil rights of customary law people in the coastal areas.

\section{Bibliography:-}

1. Samik Wahab. (1998).Perobahan Pantai danKajian Pembangunan Pantai Utara Jawa Tengah.(Report). LPMGadjahMada University.

2. AbrarSaleng. (2004). HukumPertambangan, Yogyakarta: UII Press.

3. AprilianiSoegiarto. (1988). PemanfaatanSumberAlamLautMenjelangTahun 2000 di dalamStrategiKelautan, in John Pieris (ed). PustakaSinarHarapan, Jakarta.

\footnotetext{
${ }^{43}$ Munir Fuady. (2013). Teori-Teori Besar (Grand Theory) Dalam Hukum. Jakarta: Kencana Prenadamedia Group, p. $20-21$
} 
4. BesseSugiswati. (2012)."PerlindunganHukumTerhadapEksistensiMasyarakatAdatdi Indonesia" JurnalPerspektif,17(1): 31-43.

5. BoediHarsono. (1997). HukumAgraria Indonesia (Sejarah PembentukanUndang-UndangPokokAgraria, Isi danPelaksanaannya), 7th edition. Jakarta:Djambatan.

6. Boedi Harsono. (2005). Hukum Agraria Indonesia: Sejarah Pembentukan Undang Undang Pokok Agraria, Isi dan Pelaksanaannya. Jakarta: Djambatan.

7. Bushar Muhammad. (1983).Pokok-pokokHukumAdat. Jakarta:Pradnya Paramita.

8. Charles, A.T. (2001). Sustainable Fishery Systems. London, UK: Blackwell Sciences.

9. Djaja S. Meliala. (2007). Perkembangan Hukum Perdata Tentang Orang Dan Hukum Keluarga, Bandung: CV. Nuansa Aulia.

10. E. Algra. (1985).Inleiding tot het NedherlandsPrivaatrecht, W.E.J. TjeenkWillink, Zwolle, achtiendedruk.

11. F.X. Suhardana et al. (2001). Hukum Pedata I: Bukum Panduan Mahasiswa, Jakarta:Prenhallindo.

12. George Whitecross Paton. (1964). A Texbook of Jurusprudence, 3rd ed., Univercity Press, Oxford.

13. Ibrahim, J., \& Haykal, H. (2016). Religious Communal of Indigenous Peoples in Improving Economy Through Local Wisdom (A Juridical Study on Rural Credit Institution in Bali). Hasanuddin Law Review, 1(1), 89-98. doi:http://dx.doi.org/10.20956/halrev.v1i1.216

14. JimlyAsshiddiqie. (2007).HakKonstitusionalMasyarakatHukumAdat, A Paper Presented on National Workshop, Jakarta 10 December 2007.

15. Munir Fuady. (2013). Teori-Teori Besar (Grand Theory) Dalam Hukum. Jakarta: Kencana Prenadamedia Group.

16. Pan Mohammad Faiz, PenafsiranKonsepPenguasaan Negara BerdasarkanPasal 33 UUD 1945 danPutusanMahkamahKonstitusi, $\quad$ http://jurnalhukum.blogspot.com/2006/10/penafsiran-konsep-penguasaannegara.html, accessed on 15 December 2014.

17. RohminDahuri. (2003).ParadigmaBaru Pembangunan Indonesia BerbasisKelautan, (Scientific Oration),InstitutPertanian Bogor, Indonesia.

18. RokhminDahuri, "The Challenges of Public Policy for SustainableOceans and Coastal Development: New Directions inIndonesia", in Ministerial Perspective on Ocean and Coasts atRio+10, The Global Conference on Oceans and Coasts.December 3-7, Unesco, Paris, 2001,

19. Ronald Titahelu, Paper on Indonesian Legal Center for Community Based Property Rights and Marine and Coastal Resources Management.

20. Ronald Z. Titahelu. (2014). Aneka Masalah Masyarakat Hukum Adat Dalam Pembangunan. Yogyakarta:Deepublish.

21. S.E.M. Nrahua, 29 March 2016, A Paper presented on FGD Recognition, Protection and Legal Certainty for Customary Law, In Cooperation with Postgraduate Program Unpatti with Social Science Commission of Akademi Pengetahuan Indonesia (AIPI), Ambon, Indonesia.

22. Soepomo. (1996). Bab-Bab Tentang Hukum Adat. Jakarta: Balai Pustaka.

23. Statistical Date Center and Information (KKP), the Ministry of Marine and Fisheries, Indonesia 2013. Available online at: http://statistik.kkp.go.id/

24. WinahyuErwiningsih.(2009)."PelaksanaanPengaturanHakMenguasai Negara atas Tanah Menurut UUD 1945", JurnalHukum,Special Issue: 118-136. 